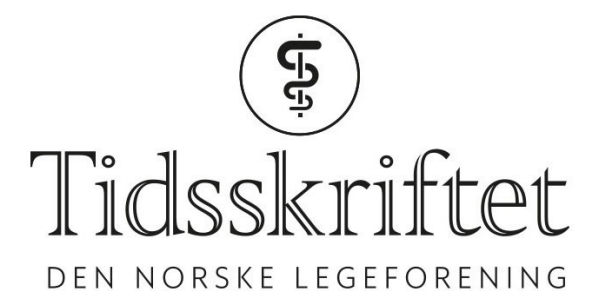

DEN NORSKE LEGEFORENING

\title{
Formative tester for læring
}

KOMMENTAR

\section{BØRGE LILLEBO}

E-post: borge.lillebo@ntnu.no

Børge Lillebo er førsteamanuensis ved NTNU.

Forfatteren har ikke oppgitt noen interessekonflikter.

Takk til Petter Gjersvik for en nyttig artikkel om eksamen (1). I tillegg til testing som gjøres på eksamen, nevnes formative tester. Formative tester er noe som trolig fortjener mer oppmerksomhet i både grunn- og spesialistutdanningen av norske leger. I artikkelen framkommer det at formative tester «brukes for å avklare hvor mye studentene kan på forhånd, slik at underviser tilpasser undervisningen til studentenes forutsetninger» og det «kan bidra til økt motivasjon for læring og bedre studievaner». Det bør også nevnes at formative tester potensierer læringen til studentene (2). Det å gjennomføre en slik test fører til bedre retensjon av kunnskap. Dette gjelder både hvis slike tester gjennomføres før, under og etter undervisning. Formative tester bør derfor ikke bare anses som en test. Det bør anses som undervisning i seg selv. Etter mitt skjønn er tiden overmoden for at formativ testing og påfølgende diskusjon mellom studenter og underviser utgjør en vesentlig større andel av timeplanfestet undervisning. Ren fagformidling fra underviser til studenter kan i større grad erstattes med individuelt selvstudium av lærebøker eller videoopptak i forkant av undervisningen. Både flervalgsoppgaver, flerresponsoppgaver og kortsvarsoppgaver er gode utgangspunkt for formative tester. Som regel blir det mer diskusjon jo mer spesifikt svar studentene må avgi, og mer diskusjon jo mindre spesifikk oppgaven er. Brukt til undervisningsformål er det ikke like viktig at det er ett klart beste svaralternativ. Mer viktig enn at studentene svarer riktig i undervisningssituasjonen, er det at studentene lærer og husker det de lærer til senere. Det er gode holdepunkt for at formativ testing er god undervisning i så henseende. For å utdanne leger som duger må vi ha god undervisning. God undervisning er viktig.

\section{LITTERATUR:}

1. Gjersvik P. Eksamenslære for dummies. Tidsskr Nor Legeforen 2020; 140. doi: 10.4045/tidsskr.20.0142. [PubMed][CrossRef]

2. Rohrer D, Pashler H. Recent research on human learning challenges conventional instructional strategies. Educ Res 2016;39: 406-12. [CrossRef] 